\title{
Determinants of community-acquired pneumonia among children aged from 2 to 59 months in Fitche General Hospital: a case control study
}

Kemal Jemal ( $\sim$ olifanjemal@gmail.com )

Salale University

Mengistu Tesema

Salale University

Teshale Mulatu Dibisa

Salale University

Gurmu Tesfaye Umeta

Ambo University

Research Article

Keywords: Pneumonia, risk factors, under-five chidren, Ethiopia

Posted Date: August 2nd, 2020

DOI: https://doi.org/10.21203/rs.3.rs-51143/v1

License: (1) This work is licensed under a Creative Commons Attribution 4.0 International License.

Read Full License 


\section{Abstract}

Background: Globally, every 39 seconds a child dies because of pneumonia. Pneumonia is one of the most common causes of morbidity and mortality among under-five children in sub-Sahara African countries. The deaths of children from pneumonia diseases are more frequent than any other infectious disease. Risk factors of pneumonia were not completely identified in Ethiopia, particularly in the study area. Therefore, this study aimed to identify the determinants of community-acquired pneumonia among children aged from 2 to 59 months.

Methods: Institutional based unmatched case-control study was employed among 246 (123 cases and 123 controls) participants in Fitche General Hospital March 2018. Data were collected using a pre-tested and standardized questionnaire, and anthropometric measurements. A systematic random sampling technique was used to select control and cases were selected consecutively. Data were analyzed using Statistical Package for Social Science Version 20. Multivariable binary logistic regression analysis was performed, and variables with a P-value $<0.05$ were considered statistically significant.

Results: Cases of 123 children diagnosed with pneumonia and controls of 123 children without pneumonia were brought to Fitche General Hospital (FGH). Malnutrition [AOR=2.85, 95\% Cl:(1.61,6.08)], children who were not exclusive breastfeeding in the first six months of their life [AOR=3.22, 95\% Cl: (1.61, 5.52)], number of occupants more than 5 people who live in one house [AOR=2.01, 95\% Cl: $(1.04,4.65)]$, use of charcoal for cooking in the house $[A O R=1.56,95 \% \mathrm{Cl}:(1.04,4.18)]$ and use of wood for cooking in the house $[\mathrm{AOR}=2.59,95 \% \mathrm{Cl}:(1.22,6.46)]$ were significantly associated with community-acquired pneumonia.

Conclusion: This study identified malnutrition, children who were not exclusive breastfeeding in the first six months of their life, number of occupants more than 5 people who live in one house and use of wood and charcoal for cooking in the house were found among the major risk factors for pneumonia. Intervention targeted to early identifying and treating malnutrition, encouraging exclusive breastfeeding practices, and preventing use of wood and charcoal for cooking in the child house is compulsory for children well being.

\section{Background}

Globally, pneumonia is one of the leading causes of morbidity and mortality among under-five years of children. ${ }^{1}$ Pneumonia is an acute respiratory infection that affects the human lungs; the lungs are made up of small sacs called alveoli, which filled with air when every person breathes. ${ }^{2}$ When an individual has pneumonia, the alveoli are filled with pus and fluid, which makes breathing painful and limits oxygen intake. $^{3}$

Worldwide, Pneumonia is one of the leading killers of children every 39 seconds and accounted for 800,000 deaths of under-five children every year. ${ }^{4}$ In low-resourced countries, pneumonia responsible for 
greater than 150 million new cases and 1.3 million preventable deaths each year. ${ }^{1,5}$ In south Asia and sub-Saharan Africa, pneumonia kills an estimated 922,000 children in 2015 which $15 \%$ of all deaths are under five years old. ${ }^{6}$

Ethiopia ranked $27^{\text {th }}$ in under-five mortality with 119 deaths per 1,000 live births. ${ }^{7}$ Almost one in every ten babies born in Ethiopia does not survive to celebrate the first birthday. ${ }^{8}$ Pneumonia, diarrhea, malaria, measles, AIDS, and sepsis are the most common diseases that causing under-five deaths, $85 \%$ in Africa and $90 \%$ in Ethiopian. ${ }^{6}$ In Ethiopia, pneumonia is a leading single disease killing under-five children. ${ }^{9}$ Annually around $3,370,000$ children encounter pneumonia contributing $20 \%$ of deaths for under-five children. ${ }^{10}$ In our previous five-year retrospective study on mortality of pediatrics, pneumonia was the first rank of the top ten diseases of mortality. ${ }^{11}$

Pneumonia has many possible causes, but the most common etiology of community-acquired pneumonia in children under-five years of age are bacteria and viruses. The most common causes of bacterial pneumonia are Streptococcus pneumoniae, causing more than $76 \%$ of bacterial pneumonia cases. ${ }^{12,13}$ Approximately $73 \%$ of community-acquired pneumonia in children is caused by viruses; Respiratory syncytial virus is the predominant viral pathogen of childhood pneumonia, accounting for $28 \%$ of incidence in under-five children. ${ }^{14}$

On the other hand, deaths from pneumonia are higher in poor rural communities as a result of household air pollution, which depend on solid fuels (wood, dung or charcoal) for cooking or heating, overcrowded homes, and less likely to be immunized against measles and whooping cough, exposure to tobacco smoke, and malnutrition. $6,15-18$

The mortality of children is easily preventable and treatable through simple and cost-effective interventions. ${ }^{19}$ Immunization, exclusive breastfeeding, appropriate complementary feeding, and proper hygiene are among preventive method ${ }^{20-22}$ while the administrations of amoxicillin and/or antibiotic treatment are the curative methods which can save lives of children. ${ }^{19}$

In Ethiopia a few studies done and little is known about the risk factors of community-acquired pneumonia. ${ }^{17}$ However, evidence-based identifying risk factors, appropriate intervention, and accurate methods of child health care are relatively scarce in North Shoa Zone Oromiya region. So far, there are no studies done regarding the determinant of pneumonia and interventions among under-five children in the study area. Therefore, this study aimed to identify the determinant of community-acquired pneumonia among children aged from 2 to 59 months at FGH.

\section{Methods}

\section{Study Design, Setting and Period}


An institutional-based unmatched case-control study design was used to assess the determinants of pneumonia in children aged between 2 to 59 months at FGH March 2018. Fitche General Hospital is a 102 bed Hospital located approximately $114 \mathrm{~km}$ from Addis Ababa in the Fitche District of the North Shoa Zone of Oromiya. It is one of the government hospitals in the Oromiya Regional State. It serves more than 1.6 million people and is a referral center for 57 Health Centers and 297 Health Posts from North Shoa Zone.

\section{Study population}

The study population consisted of children aged between 2 to 59 months and their mothers or caregivers at FGH with pneumonia (case) and those who come without pneumonia (control). The study enrolled mothers or caregivers of children aged between 2 to 59 months that are cases and controls.

Cases were defined as a child aged 2 months to 59 months who received a positive diagnosis of pneumonia by trained pediatricians according to the World Health Organization (WHO) Integrated Management of Childhood IIIness (IMNCl) guideline adopted by Ethiopian government. ${ }^{23-25}$

Controls were defined as a child aged 2 months to 59 months who brought to FGH with other than respiratory complaints (who came for immunization and growth monitoring service). Cases and Controls were recruited within the same facilities, period, and age group. The study excluded children belonging to the same household either cases or controls and mothers or caretakers who have hearing impairments.

\section{Sample size calculation and sampling procedure}

Sample size was determined using Epi Info version 7.2 software Stat Calc menu for unmatched case control study. By considering a $95 \%$ confidence level, $80 \%$ of Power, $1: 1$ ratio of controls to cases, $23.8 \%$ percent of controls exposed, 2.25 odds ratio, and $41.3 \%$ percent of cases with exposure. Through reviewing previous studies, the overcrowding is an exposure variable for pneumonia that gave the highest sample size 123 of cases and controls. ${ }^{16}$ The total estimated number of pneumonia patients (cases) for six months was 792 from the pediatric outpatient department (OPD) and the emergency department. Taking the average number of pneumonia cases per month $(792 / 6=132)$, all cases were selected consecutively during data collection until the required number of cases was obtained. Conversely, 5,178 controls from growth monitoring and expanded program of immunization (EPI) units were visited in the last six months based on the registration book. The average number of controls for one month $(5,178 / 6=$ 863 ) and the sampling fraction of control was $(863 / 123=7)$. A systematic random sampling technique was used to select the study control every seven intervals. The first participant was selected by the lottery method from $1^{\text {st }}$ to $7^{\text {th }}$ and continued every other control until we finalized the calculated sample size.

\section{Data collection tools and procedures}

Data were collected by four trained professional nurses using face-to-face interviews with a pre-tested and standardized questionnaire. The questionnaires were developed objectives based on a different 
literature review. ${ }^{16,17,18}$ It contains socio-demographic factors (age of the child, sex of child, residence, marital status of mother or caregiver, educational status of the mother or caregiver, religion, monthly income), and house factors (radio or TV in the house, number of house room and number of participants who live in the same house, the type of floor, and type of roof). It also contains childhood illnesses (history of vaccination, history of measles infection, history of HIV, and previous history of acute respiratory tract infections were reviewed from the child document). Additionally, the questionnaires contain indoor pollution factors (type of fuel energy used, cigarette smoker in the house, presence of kitchen, kitchen detached from the main house), nutritional status (exclusive breastfeeding and malnourished), and place of delivery were assessed. The questionnaire adopted by the English language and translated to the local language (Affan Oromo and Amharic), and back translation was done to see the consistency of the questionnaire. Pretest was done among a sample of 24 (12 cases and 12 controls) children age between 2 to 59 months at Kuyu General Hospital in the North Shoa Zone of Oromia region. The collected data were analyzed, reviewed and correction made for the final version of the questionnaire. Anthropometric measurement was done using a standardized and calibrated measuring tools for weight (recorded using analog weight scale to the nearest 0.1 grams) and height (to the nearest 0.1 centimeters), and mid-upper arm circumference (MUAC) was also measured using a MUAC tape-record to the nearest 0.1 centimeters. The outcome was measured according to the definition of WHO for pneumonia, age between 2 to 59 months with symptoms of cough or difficult breathing and fast breathing and/or chest in-drawing. ${ }^{20}$

\section{Data processing and analysis}

The collected data were cleaned and checked for completeness; then it was entered, compiled, and analyzed by using the Epi Info for data entry and SPSS software for analysis. Percentages and simple frequencies of the given data were calculated for each variable to describe the findings. Additionally, tables were used to assist data presentation. Bivarible logistic regression analysis was carried out to select variables for multivariable binary logistic regression. Variables with $P$ value $\leq 0.2$ in the bivariable analysis were included in a multivariable logistic regression analysis to control the confounding effect among the variables. In multivariable analysis, a p-value of less than 0.05 was considered statistically significant, and adjusted odds ratios with $95 \% \mathrm{Cl}$ were calculated to determine the association.

\section{Results}

Greater than three-fourth of cases and controls were between 2 to 23 months old. Majority 71(57.7\%) of cases and $83(67.5)$ of controls were living in urban areas. Males were the majority $55.3 \%$ of cases and $52.0 \%$ of controls. Greater than one-third $42(34.2 \%)$ of cases and one-fourth $35(28.5 \%)$ of controls were mothers or caregivers who were illiterate. Greater than three-fifth of study participants had earned monthly income more than 750 Ethiopian birr (table 1).

The majority of the study participants, $84(68.3 \%)$ of cases, and $79(64.2 \%)$ of control were fully vaccinated and $63.4 \%$ of cases and $85.4 \%$ controls had exclusive breastfeeding. Eighty-seven of 123 
cases and 106 of 123 controls delivered at health facilities and $100(81.3 \%)$ of cases and $103(83.7 \%)$ of controls of mothers or caregivers had exposed their child to sunlight properly. Twenty-nine $(23.6 \%)$ of cases and nine $(7.3 \%)$ controls had malnourished and $4.9 \%$ of cases and $6.5 \%$ of controls had a history of measles infection. Thirty-nine percent of cases and $43.1 \%$ of controls had a history of upper respiratory tract infection (table 2 ).

Table 3 shows that the potential house and indoor pollution-related risk factors for pneumonia among the study participants. More than half of the study participants had a radio, but half of them did not have television. Forty-eight cases and $37(30.1 \%)$ of controls were living in two rooms, and greater than half of the cases were living in houses occupied 3 to 5 occupants. Among the types of cooking fuels used, wood was the most common type of fuel used in cases 78(63.4\%) and controls 54(43.9\%). Greater than twothirds of cases and three-fifth of controls were living in houses with their floor being soiled. The majority of study participants were used iron sheets in their house roofs. Cigarette smoking had practiced in the study participant's house among $22 \%$ of cases and $14.6 \%$ of controls. Greater than one-fourth of cases and one-fifth of controls kitchens were not detached from the main house (table 3 ).

\section{Factors associated with community-acquired pneumonia}

Variables that fulfill bivariate criteria or $p$-values less than 0.2 were simultaneously included in multivariable logistic regression. The number of occupants who live 3 to 5 in one house and home delivery were variables that adjusted in multivariable logistic regression (table 4).

In multivariable logistic regression, Children who had malnourished three times more likely to develop community-acquired pneumonia than normal children [AOR=2.85, 95\% Cl: $(1.61,6.08)]$. Those children who were not exclusive breastfeeding in the first six months of their life has three times more likely to develop pneumonia compared to exclusively breastfeeding children [AOR=3.22, 95\% Cl: $(1.61,5.52)]$. Number of people living in the same house with the children who more than 5 people were two-fold increased to develop pneumonia compared to 1 to 3 people who live in the same house [AOR=2.01, 95\% Cl: $(1.04,4.65)]$. Regarding types of energy used for cooking, a study participant who used wood for cooking were 2.59 times more likely to develop pneumonia when compared with electric stove users [AOR=2.59, 95\% Cl:(1.22,6.46)]. Charcoal was also associated with community-acquired pneumonia (table 4).

\section{Discussion}

Acute respiratory infection, particularly community-acquired pneumonia is the foremost cause of death in resource limited-countries in children aged between 2 to 59 months. Identifying and addressing the risk factors for pneumonia are potentially open to appropriate intervention of public health importance. In this study, risk factors have been trying to identify which may have implications for health intervention programs. 
Nutritional deficits may result from any combination of insufficient caloric intake, lack of protein, and inadequate levels of micronutrients. ${ }^{26}$ We found malnutrition was significantly associated with community-acquired pneumonia. This is in line with the study done in Southwest Ethiopia. ${ }^{17}$ This may be due to impaired immunity caused by poor micronutrition and macronutrition. A previous study has been reported that impaired cellular immunity in malnourished children makes them more prone to respiratory tract infections. ${ }^{27}$ Inadequate nutrition in-utero and during infancy and early childhood is closely linked to lifelong immune deficiencies and acute respiratory infections. ${ }^{28,29}$ Acute respiratory infections generally occur more frequently, last longer, and are more severe in malnourished children. ${ }^{30}$ Typically, the mucous membranes and other mechanical structures designed to keep the respiratory tract clear are impaired, and the immune system has not developed properly in children. 3,31

We found that not exclusive breastfeeding was significantly associated with pneumonia. This result is in line with WHO comparative impact assessment of child pneumonia in 2009 which is a 15 times greater risk of death from pneumonia if not breastfeeding in the first 6 months. ${ }^{32}$ Breastfeeding has great benefits for children to prevent health problems and built all systems. Maternal-milk used for transferring to infants maternal innate immune components (lactoferrin, lysozyme, secretory lgA), influences of breast milk on immune-system matures, and enhancement of the antibody response to pathogens. ${ }^{33}$ It offers vital protection against pneumonia-related mortality. The study suggests that children who are not breastfeeding could be at greater risk than children who are either exclusively or even partially breastfeeding. ${ }^{22,34}$ This shows that not exclusively breastfeeding can be the risk factors for the development of child illness.

Crowding favors the propagation of microbial agents of respiratory tract infections that have been easily transmitted through family living in one house. Colonization of the respiratory tract of children by potential pathogens is almost universal in resource-limited countries. ${ }^{2}$ In our study, more than 5 occupants living in the same house of children were found significantly associated with communityacquired pneumonia. This finding is similar to studies done in Southwest Ethiopia, and Northwest Ethiopia. ${ }^{17,18}$ Also case-control study done in Brazil found that a linear increased the risk of pneumonia mortality with increasing people in a child's bedroom and an increasing number of occupants in the house. ${ }^{35}$ Other studies conducted in the Northwest of Ethiopia and Pakistan were not found an association between pneumonia and the number of occupants in one house. ${ }^{36,37}$ This is due to different in socio-demographic factors and number of occupants.

Our results suggest that a child whose parents used wood and charcoal for cooking was statistically significant with pneumonia. This study is in line with the study finding from WHO that show increased household pollution contributed to increasing lower respiratory infection mortality. ${ }^{38}$ Exposure to indoor household solid fuel used for cooking and the proliferation of cheap fossil-fuel-based energy has led to much greater exposure to community-acquired pneumonia in low resourced countries. ${ }^{38,39}$ In resourced countries socio-demographic index, indoor air pollution tends to decrease as cooking shifts from biofuels to natural gas and electric stove. As a result, there is a small association with lower respiratory infection 
risk. ${ }^{40}$ Despite this improvement in lower respiratory infection, improving air quality is a worthwhile goal for cognitive development, asthma, and other respiratory and cardiac outcomes. ${ }^{41}$

\section{Limitation of the study}

First, this study is limited in terms of generalizability since the study was conducted in restricted to Fitche General Hospital setting. The second limitation could be the diagnosis of pneumonia, which was based on the clinical WHO IMNCl classification guideline, which could introduce misclassification bias. Thirdly, the participants were questioned mainly about the socio-demographic characteristics, housing condition, child care practice, maternal awareness, and events that have happened not more than two weeks ago related to the child illness to minimize recall bias but still, there could be.

\section{Conclusion}

This study suggested that malnutrition, children who were not exclusive breastfeeding in the first six months of their life, the number of occupants more than 5 people who live in one house and use of wood and charcoal for cooking in the house were found among the major risk factors for developing community-acquired pneumonia for children aged from 2 to 59 months. Even though, pneumonia is an easily preventable disease, nevertheless, it still remains the leading cause of morbidity and mortality, especially in the aged between 2 to 59 months of children. Furthermore, intervention targeted to early identifying and treating malnutrition, encouraging exclusive breastfeeding practices, and preventing use of wood and charcoal for cooking in the child house is compulsory for children well being.

\section{Declarations}

\section{Ethics approval and consent to participate}

\section{Ethical consideration:}

This study was conducted in accordance with the Declaration of Helsinki. Ethical approval was gained from Salale University College of Health Sciences Ethical Review Committee; regarding written and fingerprint consent, the privacy and confidentiality of the patients, risk and benefit analysis of the study (Ref.No. CHERC/025/2018, February 20/2018 was approved. A formal letter of request for permission was submitted to FGH and permission was granted. All subjects were asked voluntary for informed written and fingerprint assent from mothers or caregivers of children after they were introduced to the purpose of the study. All the reasons why the subject was chosen and why the research was done and the right to withdraw at any time from the study were explained to the study subjects. Additionally confidentiality of all the data to be gained will be seriously maintained.

\section{Consent for publication}

N/A 
Availability of data and material

The data for this study are cannot be made publically available at the present time. It will be made available from the corresponding author when reasonable request.

\section{Competing interests}

The authors declare that they have no competing interests.

\section{Funding}

This research work is funded by Salale University. The funders had no role in study design, data collection and analysis, decision to publish, or preparation of the manuscript.

\section{Authors' contributions}

All authors contributed to data analysis, drafting or revising the article, gave final approval of the version to be published and agreed to be accountable for all aspects of the work.

\section{Acknowledgements}

The authors acknowledge Salale University, Fitche General Hospital and study participants for their cooperation.

\section{References}

1. Rudan I, Boschi-Pinto C, Biloglav Z, Mulholland K, Campbell H. Epidemiology and etiology of childhood pneumonia. Bulletin of the World Health Organization. 2008;86:408-16B.

2. Scott JAG, Wonodi C, Moïsi JC, Deloria-Knoll M, DeLuca AN, Karron RA, et al. The definition of pneumonia, the assessment of severity, and clinical standardization in the Pneumonia Etiology Research for Child Health study. Clinical infectious diseases. 2012;54(suppl_2):S109-S16.

3. Schreiber MP, Chan CM, Shorr AF. Resistant pathogens in nonnosocomial pneumonia and respiratory failure: is it time to refine the definition of health-care-associated pneumonia? Chest. 2010;137(6):1283-8.

4. Pneumonia in Children data from UNICEF https://data.unicef.org/topic/child-health/pneumonia/. 2019.

5. Zar HJ, Ferkol TW. The global burden of respiratory disease: impact on child health. Pediatr Pulmonol 2014;49:430-434.

6. Liu L, Johnson HL, Cousens S, Perin J, Scott S, Lawn JE, et al. Global, regional, and national causes of child mortality: an updated systematic analysis for 2010 with time trends since 2000 . The Lancet. 2012;379(9832):2151-61. 
7. Fekadu GA, Terefe MW, Alemie GA. Prevalence of pneumonia among under-five children in Este Town and the surrounding rural Kebeles, Northwest Ethiopia: a community based cross sectional study. Science Journal of Public Health. 2014;2(3):150-5.

8. Ethiopia demographic and health survey 2011. Addis Ababa, Ethiopia and Calverton, Maryland, USA: Central Statistical Agency and ICF International. 2012;430.

9. Deribew A, Tessema F, Girma B. Determinants of under-five mortality in Gilgel Gibe Field Research Center, Southwest Ethiopia. Ethiopian Journal of Health Development. 2007;21(2):117-24.

10. Miller NP, Amouzou A, Tafesse M, Hazel E, Legesse H, Degefie T, et al. Integrated community case management of childhood illness in Ethiopia: implementation strength and quality of care. The American journal of tropical medicine and hygiene. 2014;91(2):424-34.

11. Jofiro G, Jemal K, Beza L, Heye TB. Prevalence and associated factors of pediatric emergency mortality at Tikur Anbessa specialized tertiary hospital: a 5 year retrospective case review study. BMC pediatrics. 2018;18(1):316.

12. Iroh Tam PY, Bernstein E, Ma X, et al. Blood culture in evaluation of pediatriccommunity acquired pneumonia: a systematic review and meta-analysis. HospPediatr 2015;5:324-336.

13. Michelow IC, Olsen K, Lozano J, et al. Epidemiology and clinical characteristics of communityacquired pneumonia in hospitalized children. Pediatrics2004;113:701-707.

14. Jain S, Williams DJ, Arnold SR, et al. Community acquired pneumonia requiring hospitalizations among US children. N Engl J Med 2015;372:835-845.

15. Onyango D, Kikuvi G, Amukoye E, Omolo J. Risk factors of severe pneumonia among children aged 259 months in western Kenya: a case control study. Pan African Medical Journal. 2012;13(1).

16. Dadi AF, Kebede $Y$, Birhanu Z. Determinants of pneumonia in children aged two months to five years in urban areas of Oromia Zone, Amhara Region, Ethiopia. Open Access Library Journal. 2014;1(08):1.

17. Geleta D, Tessema F, Ewnetu H. Determinants of community acquired pneumonia among children in Kersa District, Southwest Ethiopia: facility based case control study. J Pediatr Neonatal Care. 2016;5(2):00179.

18. Markos Y, Dadi AF, Demisse AG, Ayanaw Habitu Y, Derseh BT, Debalkie G. Determinants of under-five pneumonia at Gondar University hospital, Northwest Ethiopia: an unmatched case-control study. Journal of Environmental and Public Health. 2019;2019.

19. Harris M, Clark J, Coote N, Fletcher P, Harnden A, McKean M, et al. British Thoracic Society guidelines for the management of community acquired pneumonia in children: update 2011 . Thorax. 2011;66(Suppl 2):ii1-ii23.

20. Biellik RJ, Davis R. The new World Health Organization recommendation on the 2-dose measles vaccine schedule and the way forward in African Region. The Pan African medical journal. 2017;27(Suppl 3).

21. Moore MR, Link-Gelles R, Schaffner W, et al. Effect of use of 13-valent pneumococcal conjugate vaccine in children on invasive pneumococcal disease in childrenand adults in the USA: analysis of multisite, population-based surveillance. LancetInfect Dis 2015;15:301-309. 
22. Butte NF, Lopez-Alarcon MG, Garza C. Nutrient adequacy of exclusive breastfeeding for the term infant during the first six months of life. 2002.

23. Lulseged S. Integrated management of childhood illness: a review of the Ethiopian experience and prospects for child health. Ethiopian medical journal. 2002;40(2):187.

24. Fantahun M. In what ways can Community Integrated Management of Neonatal and Childhood Illnesses (C-IMNCI) improve child health? Ethiopian Journal of Health Development. 2011;25(2):1439.

25. World Health Organisation. Revised WHO classification and treatment of childhood pneumonia at health facilities - Evidence summaries. Geneva:World Health Organisition; 2014. World Health Organisation website; Available from

http://www.who.int/maternal_child_adolesent/documents/child-pneumonia-treatment/en/.

26. Ibrahim MK, Zambruni M, Melby CL, Melby PC. Impact of childhood malnutrition on host defense and infection. Clin Microbiol Rev 2017; 30: 919-71

27. Yellanthoor RB, Shah VKB, Elangovan D. Clinical characteristics and fever resolution time in 113 children with malaria from a centre in Karnataka, India. Journal of Pediatric Infectious Diseases. 2013;8(3):111-5.

28. Griffiths PS, Walton C, Samsell L, Perez MK, Piedimonte G. Maternal high-fat hypercaloric diet during pregnancy results in persistent metabolic and respiratory abnormalities in offspring. Pediatric research. 2016;79(2):278-86.

29. Renz H, Brandtzaeg P, Hornef M. The impact of perinatal immune development on mucosal homeostasis and chronic inflammation. Nature Reviews Immunology. 2012;12(1):9-23.

30. Akombi BJ, Agho KE, Hall JJ, Wali N, Renzaho AMN, Merom D. Stunting, wasting and underweight in sub-Saharan Africa: a systematic review. Int J Environ Res Public Health 2017; published online Aug 1. DOI:10.3390/ijerph14080863.

31. World Health Organization, Child WHODo, Health A, UNICEF. Management of the child with a serious infection or severe malnutrition: guidelines for care at the first-referral level in developing countries: World Health Organization; 2000.

32. Young MK, Nimmo GR, Cripps A, Jones MA. Post-exposure passive immunisation for preventing measles. Cochrane Database of Systematic Reviews. 2014;4(4):CD010056. 1-CD. 50.

33. Jeurink P, Knipping K, Wiens F, Barańska K, Stahl B, Garssen J, et al. Importance of maternal diet in the training of the infant's immune system during gestation and lactation. Critical reviews in food science and nutrition. 2018:1-9.

34. Santo LCdE, De Oliveira LD, Giugliani ERJ. Factors associated with low incidence of exclusive breastfeeding for the first 6 months. Birth. 2007;34(3):212-9.

35. Da Fonseca Lima EJ, Mello MJG, Lopes MIL, Serra GHC, Lima DEP, Correia JB. Risk factors for community-acquired pneumonia in children under five years of age in the post-pneumococcal conjugate vaccine era in Brazil: a case control study. BMC pediatrics. 2016;16(1):157. 
36. Gedefaw M, Berhe R (2015) Gedefaw M, Berhe R. Determinates of Childhood Pneumonia and Diarrhea with Special Emphasis to Exclusive Breastfeeding in North Achefer District, Northwest Ethiopia: A Case Control Study. Open Journal of Epidemiology.2015; 5(2): 107-112.

37. Fatmi Z, White F. A comparison of cough and cold and pneumonia: risk factors for pneumonia in children under 5 years revisited. Int J Infect Dis. 2002; 6(4): 294-301.

38. Dherani M, Pope D, Mascarenhas M, Smith KR, Weber M, Bruce N. Indoor air pollution from unprocessed solid fuel use and pneumonia risk in children aged under five years: a systematic review and meta-analysis. Bull World Health Organ 2008; 86: 390-98C.

39. Kurmi OP, Lam KBH, Ayres JG. Indoor air pollution and the lung in low- and medium-income countries. Eur Respir J 2012; 40: 239-54.

40. Smith KR, McCracken JP, Weber MW, et al. Effect of reduction in household air pollution on childhood pneumonia in Guatemala (RESPIRE): a randomised controlled trial. Lancet 2011; 378: 1717-26.

41. Burnett RT, Pope CA, Ezzati M, et al. An integrated risk functions for estimating the global burden of disease attributable to ambient fine particulate matter exposure. Environ Health Perspect 2014; 122 : 397-403.

\section{Tables}

Table 1: Socio demographic characteristics among children's age between 2 to 59 months in FGH, March 2018 (n= 123 cases and 123 controls). 


\begin{tabular}{|l|l|l|}
\hline Characteristics & Cases & Control \\
\cline { 2 - 3 } & $\mathrm{N}(\%)$ & $\mathrm{N}(\%)$ \\
\hline Age of the child & & \\
\hline 24 to 59 months & $40(32.5)$ & $29(23.6)$ \\
\hline 2 to 23 months & $83(67.5)$ & $94(76.4)$ \\
\hline Sex of child & & \\
\hline Male & $68(55.3)$ & $64(52.0)$ \\
\hline Female & $55(44.7)$ & $59(48.0)$ \\
\hline Residence & & \\
\hline Rural & $52(42.3)$ & $40(32.5)$ \\
\hline Urban & $71(57.7)$ & $83(67.5)$ \\
\hline Marital status of mother or caregivers & & \\
\hline Single & $8(6.5)$ & $6(4.9)$ \\
\hline Married & $109(88.6)$ & $112(91.1)$ \\
\hline Divorced & $6(4.9)$ & $5(4.0)$ \\
\hline Religion & & \\
\hline Protestant & $17(13.8)$ & $15(12.2)$ \\
\hline Orthodox & $100(81.3)$ & $99(80.5)$ \\
\hline Muslim & $6(4.9)$ & $9(7.3)$ \\
\hline Educational status of the mother or care giver & & \\
\hline Illiterate & $42(34.2)$ & $35(28.4)$ \\
\hline $1^{\text {st }}$ cycle1-4 & $17(13.8)$ & $13(10.6)$ \\
\hline $2^{\text {nd }}$ cycle5-8 & $19(15.4)$ & $26(21.1)$ \\
\hline Secondary school9-10 & $15(12.2)$ & $12(9.8)$ \\
\hline Preparatory11-12 & $11(9.0)$ & $15(12.2)$ \\
\hline College and university & $19(15.4)$ & $22(17.9)$ \\
\hline Monthly income & & \\
\hline$\leq 750$ & $47(38.2)$ & $44(35.8)$ \\
\hline$>750$ & $76(61.8)$ & $79(64.2)$ \\
\hline & & \\
\hline & & \\
\hline
\end{tabular}

Table 2: Childhood illness and clinical care characteristics among children's age between 2 to 59 months in FGH, March 2018(n=123 cases and 123 controls). 


\begin{tabular}{|l|l|l|}
\hline \multirow{2}{*}{ Characteristics } & Cases & Control \\
\cline { 2 - 3 } & $\mathrm{N}(\%)$ & $\mathrm{N}(\%)$ \\
\hline Vaccination history & & \\
\hline Fully vaccinated & $84(68.3)$ & $79(64.2)$ \\
\hline Not fully vaccinated & $32(26.0)$ & $48(32.5)$ \\
\hline Not vaccinated & $7(5.7)$ & $4(3.3)$ \\
\hline Exclusive Breast feeding & & \\
\hline Yes & $78(63.4)$ & $105(85.4)$ \\
\hline No & $45(36.6)$ & $18(14.6)$ \\
\hline Place of delivery & & \\
\hline Home & $36(29.3)$ & $17(13.8)$ \\
\hline Health institution & $87(70.7)$ & $106(86.2)$ \\
\hline Sun light exposure & & \\
\hline Yes & $100(81.3)$ & $103(83.7)$ \\
\hline No & $23(18.7)$ & $20(16.3)$ \\
\hline Malnourished (weight for age ) & & \\
\hline Malnourished (<90\%) & $29(23.6)$ & $9(7.3)$ \\
\hline Normal (>90\%) & $94(76.4)$ & $114(92.7)$ \\
\hline History of measles infection & & \\
\hline Yes & $6(4.9)$ & $8(6.5)$ \\
\hline No & $117(95.1)$ & $115(93.5)$ \\
\hline History of HIV & & \\
\hline Yes & $4(3.3)$ & $2(1.6)$ \\
\hline No & $119(96.7)$ & $121(98.4)$ \\
\hline History of URTI & & \\
\hline Yes & $48(39.0)$ & $53(43.1)$ \\
\hline No & $75(61.0)$ & $70(56.9)$ \\
\hline
\end{tabular}

URTI-upper respiratory tract infection, HIV- Human Immune Virus

Table 3: House factors and indoor pollutions among children's age between 2 to 59 months in FGH, March 2018 ( $\mathrm{n=} 123$ cases and 123 controls). 


\begin{tabular}{|c|c|c|}
\hline Characteristics & Cases & Control \\
\hline \multicolumn{3}{|l|}{ Radio in the house } \\
\hline They don't own a radio & $53(43.1)$ & $47(38.2)$ \\
\hline They own a radio & $70(56.9)$ & $76(61.8)$ \\
\hline \multicolumn{3}{|l|}{ TV in the house } \\
\hline They don't own a TV & $75(61.0)$ & $72(58.5)$ \\
\hline They own a TV & $48(39.0)$ & $51(41.5)$ \\
\hline \multicolumn{3}{|l|}{ House size } \\
\hline Four or more rooms & $15(12.2)$ & $13(10.6)$ \\
\hline Three rooms & $25(20.3)$ & $30(24.4)$ \\
\hline Two rooms & $48(39.0)$ & $37(30.1)$ \\
\hline Single room & $35(28.5)$ & $43(34.9)$ \\
\hline \multicolumn{3}{|c|}{ Number of people living in the same house } \\
\hline 1-3 people & $44(35.8)$ & $61(49.6)$ \\
\hline 3-5 people & $66(53.7)$ & $56(45.5)$ \\
\hline$>5$ people & $13(10.5)$ & $6(4.9)$ \\
\hline \multicolumn{3}{|c|}{ Types of energy used for cooking } \\
\hline Wood & $78(63.4)$ & $54(43.9)$ \\
\hline Charcoal & 18(14.6) & $19(15.5)$ \\
\hline Cow dung & $15(12.2)$ & $17(13.8)$ \\
\hline Electric stove & $12(9.8)$ & $33(26.8)$ \\
\hline \multicolumn{3}{|l|}{ Type of floor } \\
\hline Soil & $87(70.7)$ & $74(60.2)$ \\
\hline Cement & $36(29.3)$ & $49(39.8)$ \\
\hline \multicolumn{3}{|l|}{ Type of roof } \\
\hline Grass & $39(31.7)$ & $34(27.6)$ \\
\hline Iron sheet & $84(68.3)$ & $89(72.4)$ \\
\hline \multicolumn{3}{|l|}{ Cigarette smoker } \\
\hline Absent & $96(78.0)$ & $105(85.4)$ \\
\hline Present & $27(22.0)$ & $18(14.6)$ \\
\hline \multicolumn{3}{|l|}{ Presence of kitchen } \\
\hline Absent & $20(16.3)$ & $13(10.6)$ \\
\hline Present & 103(83.7) & $110(89.4)$ \\
\hline \multicolumn{3}{|c|}{ Kitchen detached from the main house } \\
\hline Not detached & $34(27.6)$ & $28(22.8)$ \\
\hline Detached & $89(72.4)$ & $95(77.2)$ \\
\hline
\end{tabular}

Table 4: Factors (crude and adjusted odds ratios, confidence intervals, and p-value) associated with pneumonia amongchildren's age between 2 to 59 months in FGH, March 2018(n= 123 cases and 123 control). 


\begin{tabular}{|c|c|c|c|c|}
\hline \multirow[t]{2}{*}{ Explanatory variable } & \multicolumn{2}{|c|}{ Pneumonia } & \multirow[t]{2}{*}{ COR $(95 \% \mathrm{CI})$} & \multirow[t]{2}{*}{ AOR $(95 \% \mathrm{CI})$} \\
\hline & Cases & Controls & & \\
\hline $\begin{array}{l}\text { Age of child } \\
24-59 \text { months } \\
\text { 2-23 months }\end{array}$ & $\begin{array}{l}40 \\
83\end{array}$ & $\begin{array}{l}29 \\
94\end{array}$ & $\begin{array}{l}1.56(0.89,2.74) \\
1\end{array}$ & $\begin{array}{l}1.35(0.69-1.95) \\
1\end{array}$ \\
\hline $\begin{array}{l}\text { Sex of child } \\
\text { Male } \\
\text { Female } \\
\end{array}$ & $\begin{array}{l}68 \\
55 \\
\end{array}$ & $\begin{array}{l}64 \\
59 \\
\end{array}$ & $\begin{array}{l}1.14(0.69-1.88) \\
1 \\
\end{array}$ & $\begin{array}{l}1.05(0.55,1.39) \\
1\end{array}$ \\
\hline $\begin{array}{l}\text { Residence } \\
\text { Rural } \\
\text { Urban }\end{array}$ & $\begin{array}{l}52 \\
71 \\
\end{array}$ & $\begin{array}{l}40 \\
83 \\
\end{array}$ & $\begin{array}{l}1.52(0.90,2.56) \\
1\end{array}$ & $\begin{array}{l}1.07(0.71,1.58) \\
1\end{array}$ \\
\hline $\begin{array}{l}\text { Malnourished } \\
\text { Malnourished }<90 \% \\
\text { Normal }>90 \% \\
\end{array}$ & $\begin{array}{l}29 \\
94\end{array}$ & $\begin{array}{l}9 \\
114\end{array}$ & $\begin{array}{l}3.91(1.76,8.66) * \\
1\end{array}$ & $\begin{array}{l}2.85(1.61,6.08) * \\
1\end{array}$ \\
\hline $\begin{array}{l}\text { EBF } \\
\text { Yes } \\
\text { No } \\
\end{array}$ & $\begin{array}{l}78 \\
45 \\
\end{array}$ & $\begin{array}{l}105 \\
18 \\
\end{array}$ & $\begin{array}{l}1 \\
3.37(1.81,6.26) *\end{array}$ & $\begin{array}{l}1 \\
3.22(1.61,5.52) *\end{array}$ \\
\hline $\begin{array}{l}\text { Place of delivery } \\
\text { Home } \\
\text { Health institution } \\
\end{array}$ & $\begin{array}{l}36 \\
87 \\
\end{array}$ & $\begin{array}{l}17 \\
106 \\
\end{array}$ & $\begin{array}{l}2.58(1.36,4.91) * \\
1\end{array}$ & $\begin{array}{l}1.36(0.96-3.02) \\
1\end{array}$ \\
\hline $\begin{array}{l}\text { Sun light exposure } \\
\text { Yes } \\
\text { No } \\
\end{array}$ & $\begin{array}{l}100 \\
23 \\
\end{array}$ & $\begin{array}{l}103 \\
20 \\
\end{array}$ & $\begin{array}{l}0.84(0.44,1.66) \\
1\end{array}$ & $\begin{array}{l}0.71(0.35 .1 .60) \\
1\end{array}$ \\
\hline $\begin{array}{l}\text { Number of occupants } \\
1 \text { to } 3 \text { people } \\
3 \text { to } 5 \text { people } \\
>5 \text { people }\end{array}$ & $\begin{array}{l}44 \\
66 \\
13\end{array}$ & $\begin{array}{l}61 \\
56 \\
6\end{array}$ & $\begin{array}{l}1 \\
1.77(1.05,2.98) * \\
3.25(1.15,9.19) *\end{array}$ & $\begin{array}{l}1 \\
1.32(0.91,1.85) \\
2.01(1.04,4.65) *\end{array}$ \\
\hline $\begin{array}{l}\text { kitchen detached from house } \\
\text { Not detached } \\
\text { Detached }\end{array}$ & $\begin{array}{l}34 \\
89 \\
\end{array}$ & $\begin{array}{l}28 \\
95 \\
\end{array}$ & $\begin{array}{l}1.30(0.73,2.31) \\
1\end{array}$ & $\begin{array}{l}0.25(0.65,1.76) \\
1\end{array}$ \\
\hline $\begin{array}{l}\text { Type of roof } \\
\text { Soil } \\
\text { Cement }\end{array}$ & $\begin{array}{l}87 \\
36 \\
\end{array}$ & $\begin{array}{l}74 \\
49 \\
\end{array}$ & $\begin{array}{l}1.60(0.94,2.72) \\
1\end{array}$ & $\begin{array}{l}1.42(0.63,1.86) \\
1\end{array}$ \\
\hline $\begin{array}{l}\text { Cigarette smoker } \\
\text { Absent } \\
\text { Present } \\
\end{array}$ & $\begin{array}{l}96 \\
27 \\
\end{array}$ & $\begin{array}{l}105 \\
18 \\
\end{array}$ & $\begin{array}{l}0.61(0.32,1.18) \\
1\end{array}$ & $\begin{array}{l}0.59(0.28,1.13) \\
1\end{array}$ \\
\hline $\begin{array}{l}\text { Types of energy used } \\
\text { Wood } \\
\text { Charcoal } \\
\text { Cow dung } \\
\text { Electric stove }\end{array}$ & $\begin{array}{l}78 \\
18 \\
15 \\
12\end{array}$ & $\begin{array}{l}54 \\
19 \\
17 \\
33\end{array}$ & $\begin{array}{l}3.97(1.88,8.38) * \\
2.61(1.04,6.56) * \\
2.43(0.93,6.33) \\
1\end{array}$ & $\begin{array}{l}2.59(1.85,6.46) * \\
1.56(1.04,4.18) * \\
1.06(0.65,5.01) \\
1\end{array}$ \\
\hline
\end{tabular}

EBF-Exclusive Breastfeeding, COR = Crude Odds Ratio; AOR = Adjusted Odds Ratio; 95\% CI = 95\% Confidence Interval; $*$ Indicate that p<0.05 (considered significant associated). 